\title{
Drug reaction with eosinophilia and systemic symptoms (DRESS syndrome)
}

Soraia Aparecida da Silva ${ }^{1}$, Mariana Maciel Pereira de Figueiredo ${ }^{*}$, Lauro Carneiro Neto³ ${ }^{3}$ Débora Borowiak Reiss ${ }^{4}$, Mariana Amaranto de Souza Damásıo4

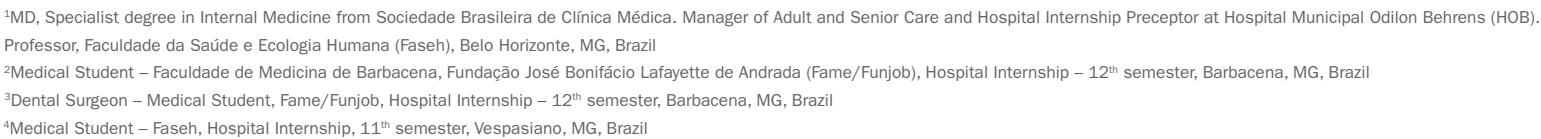

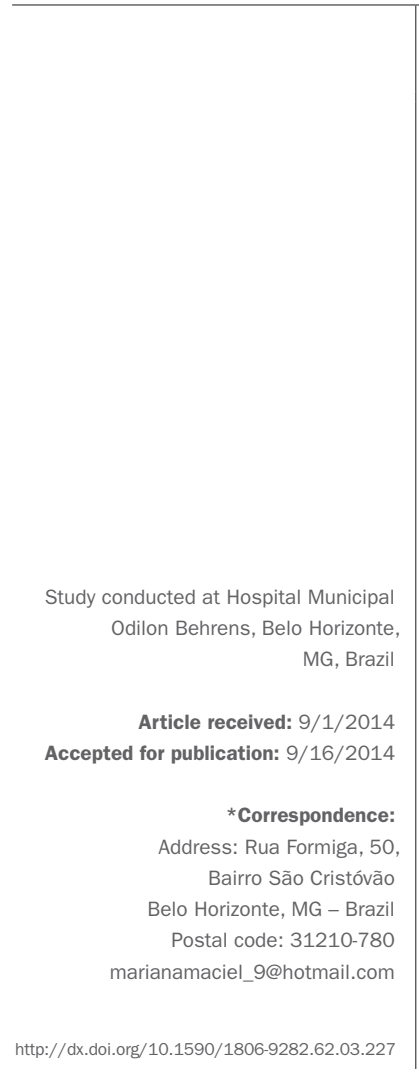

\section{SUMmARY}

Objective: To review the hypersensitivity reaction to drugs known as drug reaction with eosinophilia and systemic symptoms (DRESS syndrome), based on a case report. We also intend to discuss the difficulty and importance of disease recognition, since none of the changes is pathognomonic of this disease and failure to identify it may have disastrous consequences for the patient.

Method: To describe this case report, in addition to the information collected for clinical assessment, a literature review was performed in the PubMed and Bireme databases in order to retrieve the latest information published in literature on DRESS syndrome.

Results: The case of a 20-year old patient is reported. After anamnesis, physical examination and laboratory tests a diagnosis of DRESS syndrome was performed, characterized by rash, hematologic alterations, lymphadenopathy and lesions in target organ. This is a rare syndrome, whose frequency varies according to the drug used and the immune status of the patient, being more often associated with the use of anticonvulsants.

Conclusion: The approach and discussion of the topic are of paramount importance, in view of the potential lethality of this treatable syndrome. Recognizing the occurrence of DRESS syndrome and starting treatment as soon as possible is crucial to reduce the risk of mortality and improve prognosis.

Keywords: eosinophilia, drug eruptions, adult, drug hypersensitivity.

\section{Objective}

To conduct a review on the drug hypersensitivity reaction called drug reaction with eosinophilia and systemic symptoms (DRESS syndrome), based on a case report.

To examine the latest information published in the national and international literature on DRESS syndrome, listing the main drugs involved, disease pathogenesis, diagnostic criteria, differential diagnosis, and treatment.

To discuss the difficulty and importance of recognition, since none of the changes are pathognomonic of the disease, and failure to identify it can lead to disastrous consequences for the patient.

\section{Method}

Bibliographical research in national and international databases, including case reports and review articles, written in English and Portuguese.

The survey was conducted between May and July 2014 on the websites of Bireme/PAHO/WHO - Latin American and Caribbean Center on Health Sciences Information, and the PubMed. Keywords used included: "Eosinophilia", "drug eruption", "adult" and "drug hypersensitivity".

\section{Results}

Characterized by rash, fever, hematological abnormalities (eosinophilia and atypical lymphocytosis), lymphade- 
nopathy and lesions in target organs (liver, kidneys, lungs, brain, muscles, thyroid, pancreas, heart), DRESS syndrome is a rare example of life threatening drug hypersensitivity reaction. ${ }^{1-3}$

The incidence of this syndrome is unknown. The frequency varies depending on the drug used and the immune status of the individual. ${ }^{2}$

The period from drug exposure to onset of disease can last 2 to 6 weeks, and may persist with a series of remissions and relapses. After discontinuation of the drug, the average recovery time is 6-9 weeks. DRESS syndrome has an approximate mortality rate of $10 \% .^{2-4}$ Predictors of poor prognosis have not been identified so far, but patients with increased liver impairment and advanced age are at increased risk of death. ${ }^{2,5}$ There are reports of cases of autoimmune disease months to years after the resolution of the syndrome. ${ }^{6}$

Given that this is a rare but severe disease, we report a case of DRESS syndrome in a 20-year old female patient, black, former alcoholic and former user of cocaine, with epilepsy and non-specified neuropsychiatric disorder, admitted to Hospital Municipal Odilon Behrens (HMOB), Belo Horizonte, state of Minas Gerais, presenting fever of $38^{\circ} \mathrm{C}$, prostration and drowsiness. After two days of onset of symptoms, the patient developed jaundice (+/4), bipalpebral and lower limbs edema (++/4), macular erythema and lamellar desquamation in the face, trunk, upper and lower extremities (Figures 1 and 2) and bilateral cervical lymph node enlargement, with approximately $1 \mathrm{~cm}$ in diameter, painless and mobile. The patient had been undergoing irregular home treatment with diazepam, haloperidol and valproic acid for 4 weeks. Initially, the symptoms were treated as soft tissue infection with prescription clavulanate amoxicillin and azithromycin, suspended on hospital admission.

Laboratory tests performed on admission showed normocytic and normochromic anemia, thrombocytopenia, leukocytosis without a left shift and with mild neutropenia, atypical lymphocytosis and eosinophilia $\left(9 \% ; 973 / \mathrm{mm}^{3}\right)$, as well as elevated levels of C-reactive protein (CRP), transaminases (2 times the reference value), alkaline phosphatase (ALP), gamma-glutamyl transpeptidase (GGT), bilirubin (direct and indirect) and changes in kidney function. Serology for human immunodeficiency virus and hepatitis $B$ and $C$ were negative. Chest radiography revealed no abnormalities, while abdominal ultrasound showed mild hepatomegaly and contracted gallbladder.

In view of a possible diagnosis of DRESS syndrome, the patient was hospitalized and corticosteroid therapy

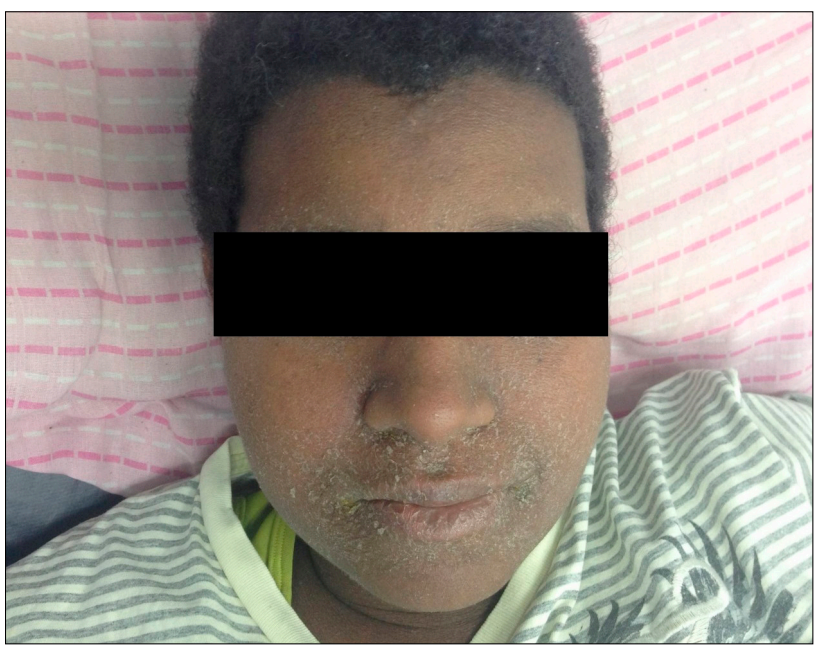

FIGURE 1 Diffuse desquamative erythema and face edema.

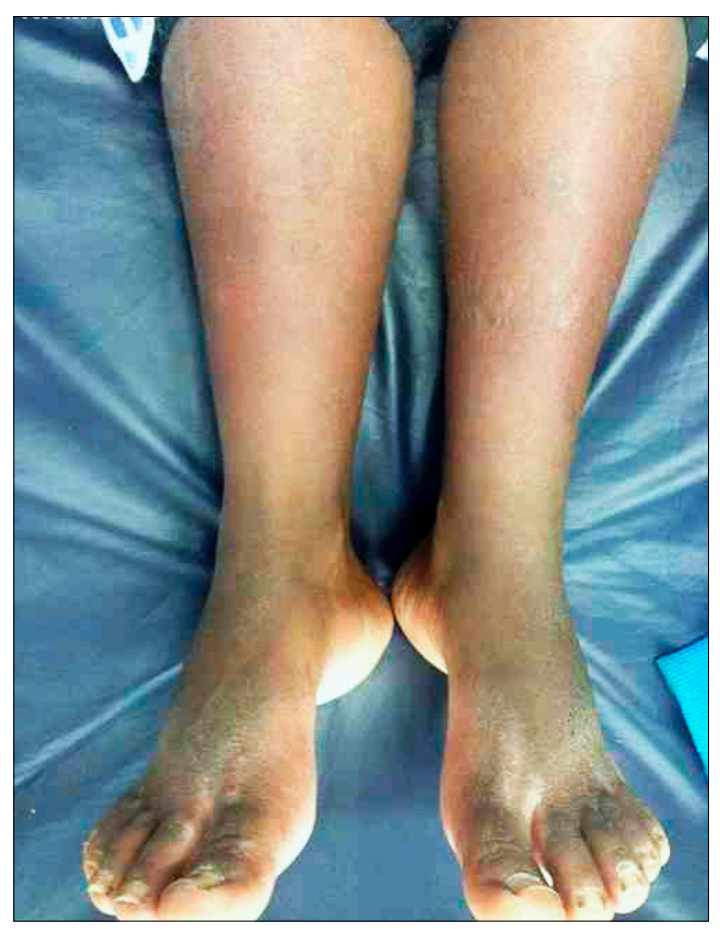

FIGURE 2 Diffuse erythema and edema in the lower limbs.

with prednisone ( $40 \mathrm{mg}$ once daily) was initiated. The drugs that the patient used at home (valproic acid and haloperidol) were suspended, and only diazepam was continued.

After ten days of the introduction of corticosteroid therapy, the patient progressed asymptomatic, afebrile, with progressive improvement of skin lesions, even though a scaly appearance continued. The dosage of liver transaminases, ALP, GGT, bilirubin, CRP, lymphocytes and eosinophils remained high, although lower than those at admission. There was improvement in kidney function. 
The patient was referred to the internal medicine outpatient clinic at HMOB for assessment until cure of DRESS syndrome.

\section{Conclusion}

Drugs associated with DRESS syndrome include: phenytoin, carbamazepine, phenobarbital, valproic acid, amitriptyline, fluoxetine, piroxicam, diclofenac, naproxen, ibuprofen, captopril, atenolol, propiutiouracil, sulfonamides, allopurinol and some antiviral/antibiotic agents, such as amoxicillin alone or in combination with clavulanate, and azithromycin. In 10 to $20 \%$ of cases, the drug possibly responsible for the syndrome may not be identified in the patient's medical history. ${ }^{1,5,7,8}$ All the drugs used by our patient could have triggered the reaction. The causality is smaller for haloperidol and diazepam, due to lack of studies showing this association.

In the pathogenesis of the disease, a particular immune response to the drug with expansion of $\mathrm{T}$ lymphocytes has been demonstrated. Studies indicate that the reactivation of human herpes virus, cytomegalovirus and Epstein-Barr virus may be related to the pathophysiology. Alleles of the human leukocyte antigen (HLA) have been associated with susceptibility to DRESS, suggesting that genetic factors can also be involved. 2,5

DRESS should be suspected in a patient who receives medical treatment and who presents with the following signs and symptoms: skin rash, fever $\left(38\right.$ to $\left.40^{\circ} \mathrm{C}\right)$, facial edema and lymphadenopathy. In 20 to $30 \%$ of patients, erythema progresses to exfoliative dermatitis. ${ }^{2}$ These findings, including peeling after morbilliform skin rash, were clinical manifestations presented by our patient.

The diagnostic criteria for DRESS syndrome are presented in Chart 1. There is no consensus on the criteria, because they lack specific clinical and laboratory characteristics to establish the diagnosis. ${ }^{9}$

Patients with DRESS should be monitored for progression of symptoms and laboratory abnormalities suggestive of visceral involvement. This patient progressed with changes in liver and kidney function. There were no other changes suggestive of organ damage.

Differential diagnoses include: Stevens Johnson/toxic epidermal necrolysis, hypereosinophilic syndrome and Kawasaki disease. ${ }^{1}$ Drug etiologies are present in DRESS syndrome, as mentioned above, and in Stevens Johnson/ toxic epidermal necrolysis, especially sulfonamides, anticonvulsants, NSAIDs and Penicillin. ${ }^{10}$ Hypereosinophilic syndrome is triggered by an exaggerated inflammatory response at the expense mainly of interleukin five (IL-5). ${ }^{11}$
Cytokines, endothelins and vasoactive mediators trigger impairment of vascular integrity in Kawasaki disease. ${ }^{12}$

Mucocutaneous manifestations are present in all of these diseases; hematologic abnormalities, such as eosinophilia and presence of atypical lymphocytosis, may be found in DRESS and hypereosinophilic syndrome. Lymphadenopathy, hepatitis, and damage to other organs can be related to all the diseases described. Differences in clinical and laboratory presentations among these differential diagnoses are summarized in Chart 2.

Treatment of DRESS primarily involves the removal of possibly involved drugs, the use of topical (for itching and inflammation of the skin) and especially systemic corticosteroids, as well as supportive measures. Due to the possible genetic correlation, family members should also be advised to avoid using the causal drug. ${ }^{4}$

The diagnosis of DRESS syndrome is a challenge due to unspecific manifestations that may hinder its recognition. Thus, to address and discuss this topic is extremely important, considering the potential lethality of a treatable syndrome. Recognizing the occurrence of DRESS syndrome and starting treatment as soon as possible is crucial to reduce the risk of mortality and improve prognosis.

\section{CHART 1 Diagnostic criteria of DRESS.}

1. Drug-related skin rash

2. Hematologic abnormalities:

Eosinophilia greater or equal to $1,500 / \mathrm{mm}^{3}$ or atypical

lymphocytosis

3. Systemic involvement:

Lymphadenopathy greater or equal to $2 \mathrm{~cm}$ in diameter or

Hepatitis (increased transaminases with values twice higher than

normal) or

Interstitial nephritis or

Interstitial pneumonitis or

Carditis

Diagnosis is confirmed in the presence of three criteria. ${ }^{9}$

\section{Resumo}

Reação a drogas com eosinofilia e sintomas sistêmicos (síndrome DRESS)

Objetivo: fazer uma revisão da reação de hipersensibilidade a drogas denominada reação a drogas com eosinofilia e sintomas sistêmicos (síndrome DRESS), com base em um relato de caso clínico. Pretende-se ainda discutir a dificuldade e importância de seu reconhecimento, uma 
CHART 2 Clinical and hematologic presentation of the differential diagnoses of DRESS syndrome.

\begin{tabular}{|c|c|c|c|c|}
\hline & DRESS syndrome & $\begin{array}{l}\text { Stevens Johnson/Toxic } \\
\text { epidermal necrolysis }\end{array}$ & $\begin{array}{l}\text { Hypereosinophilic } \\
\text { syndrome }\end{array}$ & Kawasaki disease \\
\hline $\begin{array}{l}\text { 1. Mucocutaneous } \\
\text { manifestations }\end{array}$ & $\begin{array}{l}\text { Facial edema, exfoliative } \\
\text { dermatitis, tense bullae }\end{array}$ & $\begin{array}{l}\text { Extensive formation of } \\
\text { bubbles; mucocutaneous } \\
\text { erosions }\end{array}$ & $\begin{array}{l}\text { Urticaria, angioedema, } \\
\text { infiltrated papules or nodes }\end{array}$ & $\begin{array}{l}\text { Conjunctival congestion, } \\
\text { cleft lips, "strawberry" } \\
\text { tongue, palmar erythema, } \\
\text { periungual desquamation, } \\
\text { polymorph rash }\end{array}$ \\
\hline $\begin{array}{l}\text { 2. Hematologic: } \\
\text { eosinophilia }\end{array}$ & + & - & + & - \\
\hline $\begin{array}{l}\text { Presence of atypical } \\
\text { lymphocytes }\end{array}$ & + & - & $+/-$ & - \\
\hline $\begin{array}{l}\text { 3. Systemic: } \\
\text { lymphadenopathy }\end{array}$ & + & - & + & + \\
\hline Hepatitis & + & + & + & $+/-$ \\
\hline Other organs & $\begin{array}{l}\text { Interstitial nephritis; } \\
\text { pneumonia; carditis }\end{array}$ & $\begin{array}{l}\text { Tubular nephritis; } \\
\text { tracheobronchial necrosis }\end{array}$ & $\begin{array}{l}\text { Carditis; pneumonia; } \\
\text { encephalopathy; diarrhea, } \\
\text { vomiting or nausea }\end{array}$ & $\begin{array}{l}\text { Cardiovascular } \\
\text { abnormalities; vomiting or } \\
\text { abdominal pain }\end{array}$ \\
\hline
\end{tabular}

vez que nenhuma alteração dessa doença é patognomônica e sua não identificação pode trazer consequências desastrosas para o paciente.

Método: para descrever este relato, além das informações coletadas no caso clínico, uma revisão da literatura nas bases de dados PubMed e Bireme foi realizada com o intuito de rever as informações mais recentes publicadas na literatura acerca da síndrome DRESS.

Resultados: relatou-se o caso de uma paciente de 20 anos de idade que, após anamnese, exame físico e exames laboratoriais, foi diagnosticada com síndrome DRESS, caracterizada por erupção cutânea, alterações hematológicas, linfonodomegalia e lesões em órgão-alvo. É uma síndrome rara, cuja frequência varia conforme a droga utilizada e o estado imunológico do indivíduo, sendo mais associada ao uso de anticonvulsivantes.

Conclusão: a abordagem e discussão do tema são de extrema importância, tendo em vista o potencial de letalidade dessa síndrome, que possui tratamento. Reconhecer precocemente a DRESS e instituir terapêutica é fundamental para reduzir o risco de mortalidade e melhorar o prognóstico.

Palavras-chave: eosinofilia, erupção por droga, adulto, hipersensibilidade a drogas.

\section{References}

1. Cardoso CS, Vieira AM, Oliveira AP. DRESS syndrome: a case report and literature review. BMJ Case Rep. 2011; 2011:bcr0220113898.

2. Husain Z, Reddy BY, Schwartz RA. DRESS syndrome: Part I. Clinical perspectives. J Am Acad Dermatol. 2013; 68(5):693.e1-14.

3. Cacoub P, Musette P, Descamps V, Meyer O, Speirs C, Finzi L, et al. The DRESS syndrome: a literature review. Am J Med. 2011; 124(7):588-97.

4. Husain Z, Reddy BY, Schwartz RA. DRESS syndrome: Part II. Management and therapeutics. J Am Acad Dermatol. 2013; 68(5):709.e1-9.

5. Criado PR, Avancini JM, Criado RFJ, Santi CG. Reação a drogas com eosinofilia e sintomas sistêmicos (DRESS) / Síndrome da hipersensibilidade induzida por drogas (DIHS): revisão dos conceitos atuais. An Bras Dermatol. 2012; 87(3):435-49.

6. Chen YC, Chang CY, Cho YT, Chiu HC, Chu CY. Long-term sequelae of drug reaction with eosinophilia and systemic symptoms: a retrospective cohort study from Taiwan. J Am Acad Dermatol. 2013; 68(4):459.

7. Mardivirin L, Valeyrie-Allanore L, Branlant-Redon E, Beneton N, Jidar K, Barbaud A, et al. Amoxicillin-induced flare in patients with DRESS (Drug Reaction with Eosinophilia and Systemic Symptoms): report of seven cases and demonstration of a direct effect of amoxicillin on Human Herpesvirus 6 replication in vitro. Eur J Dermatol. 2010; 20(1):68-73.

8. Bauer KA, Brimhall AK, Chang TT. Drug reaction with eosinophilia and systemic symptoms (DRESS) associated with azithromycin in acute EpsteinBarr virus infection. Pediatr Dermatol. 2011;28(6):741-3.

9. Bocquet H, Bagot M, Roujeau JC. Drug-induced pseudolymphoma and drug hypersensitivity syndrome (Drug Rash with Eosinophilia and Systemic Symptoms: DRESS). Semin Cutan Med Surg. 1996; 15(4):250-7.

10. Gerull R, Nelle M, Schaible T. Toxic epidermal necrolysis and StevensJohnson syndrome: a review. Crit Care. 2011;39(6):1521-32.

11. Gleich GJ, Leiferman KM. The hypereosinoplilic syndromes: current concepts and treatments. Br J Haematol. 2009; 145(3)271-85

12. Satou GM, Giamelli J, Gewitz MH. Kawasaki disease: diagnosis, management, and long-term implications. Cardiol Rev. 2007; 15(4):163-9. 